\title{
Impact of Oil Palm Expansion on Farmers' Crop Income and Poverty Reduction in Indonesia: An Application of Propensity Score Matching
}

\author{
Widya Alwarritzi ${ }^{1}$, Teruaki Nanseki ${ }^{2} \&$ Yosuke Chomei $^{2}$ \\ ${ }^{1}$ Graduate School of Bioresource and Bioenvironmental Sciences, Kyushu University, Fukuoka, Japan \\ ${ }^{2}$ Agriculture Faculty, Kyushu University, Fukuoka, Japan \\ Correspondence: Teruaki Nanseki, Agriculture Faculty, Kyushu University, Fukuoka-Shi, Higashi-Ku, Hakozaki, \\ 6-10-1, Japan. Tel: 81-92-642-2970. E-mail: nanseki@agr.kyushu-u.ac.jp
}

Received: October 12, 2015 Accepted: November 18, 2015 Online Published: December 15, 2015

doi:10.5539/jas.v8n1p119

URL: http://dx.doi.org/10.5539/jas.v8n1p119

\begin{abstract}
In order to solve serious problem on the lack of job opportunity and poverty in Indonesia, oil palm expansion driven by smallholders have been taken into the economic development agenda. The evidence shows that oil palm expansion by smallholders have a great performance for improving livelihood of rural community. Thus, this study aims to estimate the causal effect of oil palm expansion on farmers' livelihoods in Indonesia. Using cross-sectional data from 271 households in Riau Province, the determinants of farmers' decisions to expand oil palm farm size and the impacts of expansion are analyzed. Propensity Score Matching was employed in order to deal with self-selection biased in the evaluation of oil palm expansion impact. In the first step, logit model was applied to analyze the determinant of oil palm expansion. In the second step, each observation is matched with a similar propensity score value in order estimate the average treatment effect for the treated (ATT). Empirical results show that number of family members actively involved in oil palm cultivation, farmers' financial assets, contract farming, and distance to the market are significantly associated with likelihood for expanding farm size. Positive and significant impacts of crop income from oil palm and per capita expenditures, confirms that oil palm expansion help reducing the problem of job opportunity and poverty in Indonesia. This study implicates that, to improve oil palm expansion practice in Indonesia, several schemes must be considered: enhancing human resources development, integrating oil palm marketing schemes, and improving infrastructure facilities.
\end{abstract}

Keywords: oil palm, expansion, crop income, poverty, propensity score matching, Indonesia

\section{Introduction}

\subsection{The Importance of the Oil Palm Sector}

The demand for oil palm, a main source of biofuel and used for human and livestock consumption as well as in the pharmaceutical industry, has risen dramatically and led to rapid expansion of its cultivation in Indonesia. Indonesia has became the top oil palm producer since 2008; total oil palm plantation area expanded from 0.7 million hectares in 1990 to 10.45 million hectares in 2013, with a growth rate of approximately 500 thousand hectares per year over the past ten years (FAO, 2014). Government support has been provided through the Master Plan for Acceleration and Expansion of Indonesia's Economic Development (MP3EI), which focuses on developing oil palm plantations, with Sumatra Island as the center of production. The major goal of oil palm development is to provide job opportunities and reduce poverty in rural areas. Consistent with World Bank (2008), developing countries escaping from poverty and job opportunity problems often depend on the agricultural sector; indeed, the realization of this master plan should widen opportunities for smallholder farmers to participate actively in the oil palm sector in Indonesia.

However, oil palm is not only cultivated through large-scale operations, it is also produced by local smallholder farmers. It has been reported previously that Indonesian smallholders occupied 46\% (4.6 million hectares) of the total national oil palm plantation area (Ditjenbun, 2015). Despite the majority of smallholders lacking adequate guidance or training, farmers have continued to expand oil palm over recent decades. This trend raises several questions in terms of what makes an individual likely to expand their oil palm farm and the causal effects that might arise. Like the adoption of many other agricultural practices, oil palm land expansion can be seen as an attempt to reduce rural poverty, provide household income, and foster economic development. Since many of 
Indonesia's oil palm-farming smallholders use inadequate inputs and improper management techniques where oil palm production levels per hectare remain relatively low (Alwarritzi, Nanseki, \& Chomei, 2015) where smallholder farmers in Indonesia prefer to expand their oil palm farmland in order to achieve higher output. However, it is quite difficult to evaluate the wellbeing effects of adopting expansion farmland at household level because recent studies of incomes and poverty have relied on macroeconomic approaches and analysis at regional scales. Despite oil palm expansion occurring widely among smallholder farmers in Indonesia, only few studies have investigated the household-level factors driving farmers to expand farm sizes by smallholder farmers and its' impact among the treatment group. This makes it difficult to project the future of oil palm expansion or to evaluate its impact on farm households.

As such, the present study aims to contribute to the literature on evaluating the causal effects of farmers' agricultural activities in Indonesia, particularly oil palm land expansion by analyzing the factors associated with farmers' decisions to expand oil palm farm size and its' impact on household level. In the first step of the analysis, we examine the probability that a farmer will expand his or her oil palm farm using a probability model. In the second step, we analyze the effect of oil palm expansion on farmers' wellbeing by using propensity score matching (PSM) to account for self-selection bias (i.e., the fact that the decision to expand oil palm cultivation is not random). The effects of oil palm expansion are investigated in terms of whether expansion increases farmers' wellbeing, as indicated by farm incomes and poverty status. The resulting better understanding of the expansion decision and its impact on farmers' welfare can help policy makers understand how policy interventions can contribute to reducing rural poverty among farm households.

The rest of the paper is organized as follows. The next subsection presents trends in oil palm expansion by smallholder farmers in Indonesia over the past two decades. In Section 2, we describe the data, the PSM approach, and the treatment effect model used and explains how each variable may be associated with the decision to expand oil palm farm size. Section 3 presents the empirical results for the propensity to expand oil palm farm size and the average treatment effects of oil palm expansion. Section 4 concludes and briefly implicates the findings from overall chapter in this paper.

\subsection{Oil Palm Land Expansion and Certification Schemes in Indonesia}

The rapid expansion of agricultural land in developing countries is mainly due to the high degree of integration between rural areas and national or international economic systems as well as population pressures (Barbier, 2004). Despite economic forces, oil palm land expansion in Indonesia is also triggered by a lack of agricultural intensification, as demonstrated by the productivity gap among smallholders (FAO, 2014).

Oil palm cultivation in Indonesia began to increase dramatically in the 1990's when the government supported massive plantations for tree crops (e.g., oil palm, coffee, and cocoa) in order to generate domestic economic growth, increase export revenue, and facilitate the employment of people in remote areas. Sumatra Island was the original location for cultivation of oil palm during the period of Dutch colonialism and has the best overall environment for oil palm cultivation. Over more than two decades of oil palm development, Sumatra remains the largest and most productive area, housing $70 \%$ of the national mature oil palm area and $75 \%$ of oil palm production. In recent decades, oil palm expansion in Indonesia has spread widely to outer Sumatra. The second major area for expansion and production is Kalimantan, where oil palm land has increased dramatically to 1.4 million hectares in the last five years.

The Indonesian Government predicts that oil palm plantations will increase in area by 500,000 hectares each year while production by smallholder will reach almost 31 million tones in 2015 . Thus, concerning national trends in oil palm development, the Indonesian government established the official Platform for Sustainable Oil Palm Plantations as a national certification scheme (land property right) in order to improve smallholder farmers' capacity to increase oil palm productivity and mitigate the environmental impacts of plantations (UNDP, 2015). To support the rapid expansion of oil palm plantations in Indonesia, the scheme offers certification to smallholders at the village level in order to support their access to markets by: 1) collaborating with the national oil company to promote oil palm as the main source of biodiesel; 2) establishing a fair international market price; 3) working in partnership with the private sector; and 4) creating an industry that promotes sustainable Indonesian oil palm products.

\subsection{Literature Review}

Beside the availability of unproductive land in Indonesia, massive oil palm expansion may be induced by the high yield gap among oil palm farmers that significantly influenced by poor application of the input use and unobserved factors such as human resources availability (Alwarritzi, Nanseki, \& Chomei, 2015a). The socio-economic factor determining smallholder farmers' decision on expanding their oil palm farmland ware 
captured. The recent study by Alwarritzi, Nanseki, and Chomei (2015b) found that the likelihood on expanding oil palm farmland were determined by the actual benefit earned from oil palm: getting higher income, owning oil palm land property right and facilitated with financial credit access from the government. Furthermore, geographical attribute has contributed to the probability of farmers' decision to expand oil palm farmland; the availability of peat land in Riau Province, Indonesia was found increasing the likelihood to expand farmland. Several studies have investigated spatial and demographic factors associated with the expansion of land used for oil palm in Indonesia. Gatto, Wollni, and Qaim (2015) examined that distance from oil palm plot to roads and access to capital for buying inputs or raw materials contributed positively to driving oil palm expansion in Sumatra. Additionally, the high financial returns generated by oil palm plantations compared to rubber or rice cultivation were found motivating farmers to expand oil palm land in Jambi Province (Rist, Feintrenie, \& Levang, 2010). However, oil palm not only generates high returns on investment; it also has other advantages, such as requiring less labor and enabling partnerships with banks and palm oil refinery companies. The prevailing evidence suggests that there are several determinant inducing oil palm farmland expansions such as socio-economic motivation and geographical variables.

Oil palm expansion potentially has significant social and livelihood implications in rural Indonesia. The associated land transformations have given rise to a number of socio-economic concerns, including whether the crop can contribute to sustainable rural livelihoods, while ensuring social equality (Cramb \& Curry, 2012; McCarthy, 2010). After being implemented during two decades, the wellbeing effect from the oil palm expansion deserves special attention, especially since the recent land expansion for oil palm are largely driven by smallholder farmers. As explained in the previous sub-section, smallholder farmers is accounted for nearly $50 \%$ of the total oil palm area and for $36 \%$ of the total fresh fruit bunch (FFB) production in Indonesia, the world's leading oil palm producer. The government expects that, if smallholder farmers sustainably expand the oil palm farmland, the lack of job opportunity and poverty problems may be reduced. This is inline with Finan, Sadoulet and Janvry (2004), which highlighted the role of the land as an instrument to reduce the poverty. Using semi-parametric estimation, they analyzed that an additional hectare of land increases welfare on average depends on the controlled variable of household in rural Mexico. However, the outcome of oil palm adoption on farmers' livelihoods is still becoming a debated topic globally. Cahyadi and Waibel (2013) emphasized that oil palm land expansions play an important role on improving farmers' livelihood through increased incomes, poverty reduction and rural development in Indonesia. The study of Krishna et al. (2015), which employing endogenous switching regressions to model the impacts of oil palm adoption using total annual consumption expenditures as a proxy for household welfare in Indonesia, found that oil palm adopter shown to be signify increasing their per capita annual consumption expenditure and improving welfare status than the counterfactual. In contrast, several practice of oil palm expansion by smallholder farmers affected to an increasing vulnerability and economic marginalization of rural community (McCarthy, 2010; Rist et al., 2010). Further, in a broad sense, farmers' specialization in non-food cash crops like oil palm has been criticized for decreasing on farm production diversity, declining significance of subsistence food crops, greater farmer dependency on trade and markets to satisfy nutritional needs, and increased livelihood vulnerability to price shocks on international commodity markets (Pellegrini \& Tasciotti, 2014; Jones et al., 2014).

\section{Data and Methods}

\subsection{Data and Sampling Procedures}

We carried out household-level interviews in four neighboring villages in Riau Province that have undertaken oil palm cultivation over the last few decades, from 1990 to the survey period in 2015. A total of 271 sample households from four major villages in Riau were purposively selected based on the characteristics of the plantation scheme. Two villages (Mekar Jaya and Makmur) are under Nucleus Estate Smallholders (NES schemes) that were established in the 1990's, and two villages are independently cultivating oil palm. We then randomly selected farmers involved with each scheme, whether they had expanded their oil palm or not, from a list provided by leaders of farmers' organizations and villages. For the purpose of this study, treated group are classified as farmers who expanded their farm size over two decades named as "expansion" group, while untreated group are the farmers who did not expand oil palm farm size notated as the "non-expansion" group.

A structured questionnaire was designed to gather detailed information regarding farm characteristics (e.g., farm size, year of expansion, number of trees, yield, and income), household and farmers' characteristics such as education, age, number of family members actively involved with the plantation, social capital including extension visits, farmers' association membership, and contract farming scheme, capital assets which cover the information about vehicle ownership, total land area, land certificate ownership, and credit access), market distance and geographic factors (e.g., distance to the market and soil conditions). Survey on household annual 
expenditures for food and non-food consumption were gathered in order to gain information on farmers' per capita expenditure as well as their consumption behavior. In order to confirm important informations on oil palm farming practices in the study area, we also conduct group discussions with the leaders of farmers' groups.

\subsection{Model Specification}

\subsubsection{Logit Estimates and Empirical Models}

Farmers' decisions to expand oil palm farm size are presented in dichotomous dependent variables. The $Y$ dependent variables comprise the decisions of farmers to expand their oil palm farmland several years after they first cultivate; $Y$ takes a value of one if farmers expanded farm size, and zero otherwise. In our logit model, the probability of an individual farmer expanding farmland, notated as $\operatorname{Prob}(\mathrm{Y}=1 \mid \mathrm{x})$, given socioeconomics factors and geographical characteristic $\mathbf{x}^{\prime}$ and $\beta$ is impact of the change in $\mathbf{x}^{\prime}$ on the probability. $\wedge\left(\mathbf{x}^{\prime} \beta\right)$ is the value of the logistic cumulative density function associated with each possible value of the underlying index. The model can be expressed as follows,

$$
\operatorname{Prob}(\mathrm{Y}=1 \mid \mathrm{x})=\wedge\left(\mathbf{x}^{\prime} \beta\right)=\frac{e^{x^{\prime} \beta}}{\left(1+e^{x^{\prime} \beta}\right)^{2}} \beta_{j}=\frac{\exp \left(\mathbf{x}^{\prime} \beta\right)}{1+\exp \left(\mathbf{x}^{\prime} \beta\right)}
$$

with marginal effect for normal distribution,

$$
\partial p / \partial \mathrm{x}_{\mathrm{j}}=\wedge\left(\mathbf{x}^{\prime} \beta\right)\left[1-\wedge\left(\mathbf{x}^{\prime} \beta\right)\right] \beta_{j}=\frac{e^{x^{\prime} \beta}}{\left(1+e^{x^{\prime} \beta}\right)^{2}} \beta_{j}
$$

In addition, the coefficients in the logit analysis are estimated using maximum likelihood estimation and serve to indicate the direction of influence on the probability. The marginal effect of each independent variable is calculated and indicated by the calculated changes in probability. We thus use a logit model to investigate the factors influencing farmers' decisions to expand oil palm cultivation. A complete description of the variables, measurement units, and expected coefficient signs is presented in Table 1 . The explanatory variables included in the vector X relate to human capital (household head's age $(A G E)$ and level of education (EDUCATION), number of family members in the household (FSIZE), total family labor hours worked on the oil plantation $(F A M L A B)$ ), financial capital and assets (availability of non-farm income (NONFI), availability of other farm income (OTHFI), access to agricultural credit (CREDIT), land ownership status $(L O W N)$, number of vehicles such as motorbikes owned (MOTORBIKE)), social capital (contact with extension services (EXTENSION), membership in a farmers' association (GROUP)), market access (contract farming system (CONTRACT), distance to the nearest refinery company (DISTANCE)). The model also controlled for a variety of geographical conditions (e.g., soil type) that vary among the four villages by incorporating a regional dummy variable for soil type (SOIL).

This study measures the availability of human capital using farmers' education and the number of family members involved in oil palm cultivation. Many studies have found that agricultural decision-making depends on farmers' education levels. Mital and Kumar (2000) found significant impact of education on farmers' decisions to adopt certain seed varieties. Referring to the Chayanovian theory of the peasant economy (Rahman, 2008), subsistence pressure (measured by the number of family members in a farm household) is incorporated into our model. In addition, farmers with more family members involved in farming were found to be more likely to undertake agricultural diversification in the Netherlands (Hassink, Hulsink, \& Grin, 2012). Human capital is generally expected to have positive effects on the land expansion decision. The impact of the farmer's age, however, is unclear. Herath and Takeya (2003) argued that as age and experience increases, the ability of a farmer to adopt a new innovation decrease, while risk aversion and learning from current management practices might increase. On the other hand, farmers' experience may increase farming knowledge. The impact of farmers' ages on oil palm expansion thus cannot be predicted based on previous findings.

The evidence on the impact of land ownership status varies. Herath and Takeya (2003) found that land ownership had a significantly negative effect on farmers' decisions to intercrop in Sri Lanka and showed that most farmers used rented land. In the present study, an indicator for having a land ownership certificate is included in the model because this is an important factor for farmers in the study area when deciding whether to expand oil palm cultivation, particularly as such a certificate can be used as collateral for credit from formal or informal financial institutions. Hence, the impact of this variable is expected to be positive. In addition, dummy variables for off-farm income are included because of the relative importance of non-agricultural activities in supporting the expansion of oil palm. However, the role of off-farm income in farmers' decisions remains unclear. According to Dimara and Skuras (1998), an increase in off-farm annual work units decreased the probability of Greek farmers deciding to enhance their farming technology, but this effect was not significant. Based on previous studies, it is 
thus difficult to ascertain the sign of this variable. In contrast, the effects of extension agent contact and membership in a farmers' association are expected to be positive and significant: extension access and farmers' group participation should increase the efficiency of oil palm production in the study area. Moreover, interactions with these formal institutions increase farmers' knowledge, making them more motivated to expand and develop oil palm farmland. Recent studies show that contract farming is an institutional innovation that has a positive effect on farm productivity (Verhofstadt \& Mertens, 2014). The Contract farming for oil palm plantations has been in existence in Indonesia since the 1990's, when NES scheme farmers started to cultivate oil palm in order to provide technical guidance and market access. Currently, independent farmers have also developed contracts with the nearest refinery company in order to sell their products. Overall, contract farming is expected to positively influence expansion.

The distance from farmers' oil palm plot to the market is an important variable influencing farmers' decisions to expand oil palm land. Since the limitation of infrastructure facility in the study site and the high cost of transportation of product, then the oil palm farmers prefer to sell their product to the nearest refinery mills. This assumption is inline with Verhofstadt and Mertens (2014), when farmers can easily access markets, the probability of increasing cultivation area will also be higher. Based on this evidence, market distance is expected to have a negative effect. Similarly, the nearer the plot to the refinery, the greater we expect the likelihood of expanding farm size to be higher. Lastly, the trend of oil palm expansion has increased in recent years, mostly on peat land, and the availability of peat land in the study area encourages oil palm farmers to expand their farmland (Gatto, Wollni \& Qoim, 2015). This variable is thus expected to positively influence farmers' decisions.

\subsubsection{Propensity Score Matching}

The PSM approach develops a statistical comparison group by matching every individual from the adopter group with a non-adopter with similar characteristics. In essence, matching models attempt to create the conditions of an experiment in which adopters and non-adopters are randomly assigned, allowing one to identify a causal link between choices and outcome variables. We use crop income from oil palm and wellbeing status (indicated by a dummy variable based on per capita expenditure (PCE)) as the outcome variable: one if farmers are living above the food poverty line and zero otherwise. Household PCE was calculated based on household purchasing power for consumption, as obtained from the survey. The food poverty line was constructed based on the standard commonly used in Indonesia in which one day of per capita expenditures is not less than 1 USD (Deaton, 2003).

PSM is a two-step procedure. First, a probability model is calculated for the decision to expand farm size via probability estimation; this provides a decision propensity score for each observation. In the second step, each observation in the treated group (expansion) is matched to one in the untreated group (non-expansion) with a similar propensity score value in order to estimate the average treatment effect for the treated (ATT), denoted as

$$
A T T=E\left(Y_{1}-Y_{0} \mid \mathrm{x}, D=1\right)=E\left(Y_{1} \mid \mathrm{x}, D=1\right)-E\left(Y_{0} \mid \mathrm{x}, D=1\right)
$$

where $D$ is an indicator variable equal to one if the farmer expanded oil palm farm size and zero otherwise. $Y_{1}$ is the outcome for the expansion observation, $Y_{0}$ is that for the non-expansion observation, and $\mathbf{x}$ is a vector of control variables. When farm size expansion is randomly adopted, we can replace $E\left(Y_{0} \mid \mathbf{x}, D=1\right)$ with $E\left(Y_{0} \mid \mathbf{x}, D\right.$ $=0)$. However, as mentioned above, the groups are not randomly distributed, and $E\left(Y_{0} \mid \mathbf{x}, D=1\right)$ is unobservable. Therefore, we employ two methods to match the expansion and non-expansion observations: nearest neighbor matching (NNM) and kernel-based matching (KBM).

After matching, one must run a balancing test to ascertain whether the differences in the covariates between the two groups have been eliminated, in which case the matched comparison group can be a considered a plausible counterfactual (Ali \& Abdulai, 2010). Although several versions of balancing procedure exist, the most widely used is the mean absolute standardized bias (MASB) approach. Thus, we employed the MASB method suggested by Rosenbaum and Rubin (1985) in which the standardized difference should be less than $20 \%$ to confirm success in the matching process. Additionally, Sinsesi (2004) proposed comparing the pseudo $R^{2}$ and $p$-values of the likelihood ratio test for the joint insignificance of all regressors after matching: the pseudo $R^{2}$ should be lower, and the joint significance of covariates should be rejected (i.e., there should be an insignificant $p$-value for the likelihood ratio). Many studies have analyzed the effects of farmers' decisions to adopt alternative technologies or farming practices in terms of farmers' wellbeing but it is still lack of the study focusing on the impact of oil palm expansion. Specifically, this study estimates the impact of oil palm farm expansion on two outcome variables: net oil palm income and the poverty headcount ratio using the international standard of per capita expenditure for consumption. 
Table 1. Variables used and definitions

\begin{tabular}{|c|c|c|c|}
\hline Variable & Unit & Definition & Expected Sign \\
\hline \multicolumn{4}{|l|}{ Dependent variable } \\
\hline Expand oil palm farm size & Dummy & 1 if farmer expanded farm size, 0 otherwise & \\
\hline \multicolumn{4}{|l|}{ Independent Variable } \\
\hline \multicolumn{4}{|l|}{ Human Capital } \\
\hline \multirow[t]{3}{*}{ AGE } & Ordered & $1=30-40$ Years & $+/-$ \\
\hline & & $2=41-60$ & \\
\hline & & $3=>60$ & \\
\hline \multirow[t]{4}{*}{ EDUC } & Ordered & $1=$ Elementary school & + \\
\hline & & $2=$ Junior high school & \\
\hline & & $3=$ High school & \\
\hline & & $4=$ Academy/university & \\
\hline FAMSIZE & Person & Number of family members & + \\
\hline FAMLAB & Hours & Total hours of family labor working in oil palm farm & + \\
\hline \multicolumn{4}{|l|}{ Financial and Asset } \\
\hline NONFI & Dummy & 1 if the farmer has non-agricultural income, 0 otherwise & $+/-$ \\
\hline OTHFI & Dummy & $\begin{array}{l}1 \text { if the farmer has other farm income sources besides oil } \\
\text { palm, } 0 \text { otherwise }\end{array}$ & $+/-$ \\
\hline CREDIT & Dummy & $\begin{array}{l}1 \text { if the farmer receives agricultural credit from a bank, } 0 \\
\text { otherwise }\end{array}$ & + \\
\hline LOWN & Dummy & 1 if the farmer has a land certificate, 0 otherwise & + \\
\hline MOTORBIKE & Number & Number of motorbikes owned by the household & \\
\hline \multicolumn{4}{|l|}{ Social Capital } \\
\hline EXTENSION & Times & Number of visits of extension agent each year & + \\
\hline GROUP & Dummy & 1 if the farmer is a member of a farmers' group, 0 otherwise & + \\
\hline \multicolumn{4}{|l|}{ Market Access } \\
\hline CONTRACT & Dummy & 1 if the farmer is in a contract farming scheme, 0 otherwise & + \\
\hline DISTANCE & $\mathrm{Km}$ & Distance from the oil palm plot to the nearest market & - \\
\hline \multicolumn{4}{|l|}{ Regional Dummy } \\
\hline SOIL & Dummy & 1 if soil type of farmers' plot is peat, 0 otherwise & + \\
\hline
\end{tabular}

\section{Results and Discussion}

\subsection{Descriptive Analysis of Socioeconomic and Physical Conditions}

Tables 2 and 3 summarize the variables used in the model as well as farm information, including input costs, net oil palm income, yields, household per capita expenditures, and trends in farm size expansion. On average, farmers in the study area are in the less productive life phase, with an average age of 50 years and insignificant differences between the groups. In both groups, farmers generally have only a secondary education, implying that oil palm farmers are running plantations without any educational background. The data shows that most farmers learned farming practices from experience, enhanced by knowledge sharing among farmers. The average family size was five, implying that a typical farm household has at least two children who can be potential successors in running the future oil palm operation. Regarding family members involved with oil palm farming activities, we found that farmers in the expansion group allocated more hours working on the farm than the non-expansion farmers did. Based on our observations during the survey, expansions farmers apply fertilizer by themselves in order to ensure proper input use and directly check farm conditions. 
Table 2 shows that average values for financial and asset variables differ significantly between the groups. Interestingly, a significantly higher percentage of non-expansion farmers have non-farm income sources. For example, they are government employees, run small businesses at home, are oil palm middlemen, transport oil palm fruit to refineries, and work as farm laborers. As explained in the previous section, the Indonesian government supports oil palm expansion by facilitating farmers' access to bank loans and providing them with land certificates. Indeed, the average values for the credit use and land certificate ownership variables differ significantly between groups, suggesting that farmers who expanded oil palm land were aided by credit and used land certificates as collateral to help obtain it. Farmers' group membership and extension agents' visits differ significantly between the two groups, implying that farmers gain knowledge mostly from social interactions within farmers' groups and with extension staff. This aligns with the fact that farmers have only limited educational backgrounds in farming. Thus, the role of farmers' groups and extension services are very important for transferring farming knowledge, particularly for farmers with more than two hectares of farmland. Furthermore, the distance to the market is less than $7 \mathrm{~km}$ on average, implying that farmers tend to select areas close to refinery mills to cultivate oil palm. A long distance from the plot to the mill may increase the cost of transportation and the risk of damage to the oil palm fruit. Lastly, $12 \%$ of non-expansion farmers cultivated oil palm in peat soil, suggesting that farmers' operating with peaty soil conditions face technical constraints.

A surprising result is also seen in household PCE; the difference between groups is not statistically significant, implying that farmers who expanded oil palm production may spend their income on agricultural investments, buying luxury goods, or paying off credit. Thus, this figures inline with the common wisdom that suggest the non-linearity of the relationship with calorie consumption with income growth. The study of Yu, Gao, and Zeng (2014), found that when households enter the affluent stage, they will swift to a strong preference for palatable and high quality food and stuffs. Many farmers had expanded the size of their oil palm farm compared to the area they cultivated in the 1990s (Table3). Indeed, $73 \%$ of farmers had expanded their oil palm farms to be on a medium or large scale. Farmers in the NES program started oil palm cultivation in the 1990s, and each received 2 ha of land from the government. Based on aggregate calculations, input costs, oil palm revenues, oil palm income, and total income are statistically different between the two groups. However, production per hectare is not, implying that in terms of yield, the groups have similar outcomes.

\subsection{Logit Estimation Results}

The results of estimating the empirical logit model are presented in Table 4; they were obtained using Stata 13 and analyzing cross-sectional data on 271 respondents in the study area. The McFadden pseudo $R^{2}$ is 0.68 , indicating that $68 \%$ of the variation in the probability of a farmer expanding oil palm cultivation is explained by the variables included in the model. A goodness-of-fit measure for the logit model can be computed using the percentage correctly predicted; our model correctly predicts $92 \%$ of farmers' decisions to expand oil palm farmland. Since the coefficient of logit estimation result cannot be directly interpreted, the average marginal effects of the explanatory variables on the probability of deciding to expand are presented in Table 4; note that marginal effects are dependent on the units of measurement for the independent variables (Greene, 2013).

Based on the probability specification estimates (Table 4), it is found that hours worked by family members in oil palm farming, access to credit, land ownership status, number of extension visits per year, farmers' group membership, and distance to the refinery are positively associated with the likelihood of a farmer expanding oil palm land. Non-agricultural income is shown to have an insignificant effect. Since the coefficient of logit estimation result cannot be directly interpreted, we also provide the marginal effects of independent variables. The results of calculating marginal effects on the decision to expand oil palm show that a change in the dummy variable for having credit from a financial institution for agricultural purposes increases the probability of a farmer expanding his or her farmland by 0.44 (holding all other variables constant). 
Table 2. Descriptive statistics for the variables used and farm information

\begin{tabular}{|c|c|c|c|c|c|c|c|}
\hline \multirow[t]{2}{*}{ Variable } & \multicolumn{2}{|c|}{$\begin{array}{c}\text { All } \\
(\mathrm{N}=271)\end{array}$} & \multicolumn{2}{|c|}{$\begin{array}{c}\text { Expansion } \\
(\mathrm{N}=199)\end{array}$} & \multicolumn{2}{|c|}{$\begin{array}{c}\text { Non-expansion } \\
(\mathrm{N}=72)\end{array}$} & \multirow[t]{2}{*}{ Difference } \\
\hline & Mean & SD & Mean & SD & Mean & SD & \\
\hline \multicolumn{8}{|l|}{ Human Capital } \\
\hline AGE & 1.94 & 0.30 & 1.94 & 0.25 & 1.92 & 0.40 & 0.02 \\
\hline EDUC & 2.02 & 0.95 & 2.04 & 0.99 & 1.96 & 0.84 & 0.08 \\
\hline FAMSIZE & 4.90 & 1.16 & 4.95 & 1.18 & 4.74 & 1.12 & 0.21 \\
\hline FAMLAB & 41.78 & 4.32 & 41.86 & 4.30 & 41.55 & 4.41 & 0.32 \\
\hline \multicolumn{8}{|l|}{ Financial Capital and Assets } \\
\hline NONFI & 0.41 & 0.49 & 0.38 & 0.49 & 0.49 & 0.50 & $-0.11 *$ \\
\hline OTHFI & 0.24 & 0.43 & 0.26 & 0.44 & 0.18 & 0.39 & 0.08 \\
\hline CREDIT & 0.75 & 0.43 & 0.88 & 0.31 & 0.35 & 0.48 & $0.53 * * *$ \\
\hline LOWN & 0.79 & 0.41 & 0.79 & 0.41 & 0.32 & 0.47 & $0.65 * * *$ \\
\hline MOTORBIKE & 1.94 & 0.88 & 1.89 & 0.79 & 2.05 & 1.08 & $-0.16^{*}$ \\
\hline \multicolumn{8}{|l|}{ Social Capital } \\
\hline EXTENSION & 2.42 & 2.61 & 2.57 & 2.69 & 2.03 & 2.34 & $0.54 *$ \\
\hline GROUP & 0.65 & 0.48 & 0.69 & 0.46 & 0.55 & 0.50 & $0.14 * *$ \\
\hline \multicolumn{8}{|l|}{ Market Access } \\
\hline CONTRACT & 0.85 & 0.36 & 0.99 & 0.10 & 0.45 & 0.50 & $0.54 * * *$ \\
\hline DISTANCE & 6.41 & 3.47 & 6.24 & 3.30 & 6.87 & 3.87 & $0.63^{*}$ \\
\hline \multicolumn{8}{|l|}{ Regional Dummy } \\
\hline Soil & 0.10 & 0.30 & 0.09 & 0.28 & 0.12 & 0.33 & -0.04 \\
\hline Oil palm farm size $(\mathrm{Ha})$ & 4.65 & 2.59 & 5.62 & 2.39 & 2.02 & 0.23 & $3.59 * * *$ \\
\hline Oil palm income (Million IDR) & 89.55 & 62.46 & 108.82 & 61.73 & 37.29 & 20.34 & $71.53 * * *$ \\
\hline PCE (‘000 IDR) & 14.32 & 67.36 & 14.33 & 65.97 & 14.26 & 71.47 & 0.07 \\
\hline Wellbeing status & 0.58 & 0.52 & 0.62 & 0.49 & 0.51 & 0.51 & $0.11^{*}$ \\
\hline
\end{tabular}

Table 3. Farm characteristics and household information by land size

\begin{tabular}{llll}
\hline Variable & $\begin{array}{l}\text { Small scale } \\
<\mathbf{5 ~ H a}\end{array}$ & $\begin{array}{l}\text { Medium Scale } \\
\mathbf{6 - 8} \mathbf{~ H a}\end{array}$ & $\begin{array}{l}\text { Large Scale } \\
>\mathbf{8 ~ H a}\end{array}$ \\
\hline Number of farmers (\%) & 26.57 & 68.27 & 5.17 \\
Input use for oil palm (Million IDR) & 8.91 & 21.05 & 50.08 \\
Oil ralm revenue (Million IDR) & 45.15 & 123.44 & 244.20 \\
Total income (Million IDR) & 37.44 & 103.26 & 196.30 \\
Annual oil palm yield (Ton/Ha) & 19.21 & 19.79 & 18.80 \\
\hline
\end{tabular}

Note for Tables 2 and 3. Data from author's survey in 2015. IDR = Indonesian Rupiah, 1 USD = 13,000 IDR. Wellbeing status was measured as dummy variable where 1 denotes PCE not less than 1 USD and 0 otherwise. Total income is accumulated from oil palm and other income sources. ${ }^{* *} \mathrm{p}<0.01, * * \mathrm{p}<0.05,{ }^{*} \mathrm{p}<0.10$. 
Table 4. Logit estimation of factors influencing farmers' decisions to expand oil palm farm size

\begin{tabular}{|c|c|c|c|c|}
\hline \multirow{2}{*}{ Variable } & \multicolumn{2}{|c|}{ Logit estimates } & \multicolumn{2}{|c|}{ Marginal effect } \\
\hline & Coef. & Std. Err. & $\mathrm{Dy} / \mathrm{dx}$ & Std. Err. \\
\hline \multicolumn{5}{|l|}{ Human Capital } \\
\hline AGE & -0.69 & 1.05 & -0.08 & 0.12 \\
\hline EDUC & 0.14 & 0.31 & 0.02 & 0.04 \\
\hline FAMSIZE & -0.12 & 0.26 & -0.01 & 0.03 \\
\hline FAMLAB & $0.18^{*}$ & 0.07 & $0.02 *$ & 0.01 \\
\hline \multicolumn{5}{|c|}{ Financial Capital and Assets } \\
\hline NONFI & -0.64 & 0.59 & -0.07 & 0.07 \\
\hline OTHFI & 0.43 & 0.63 & 0.05 & 0.07 \\
\hline CREDIT & $3.63 * * *$ & 0.72 & $0.41 * * *$ & 0.11 \\
\hline LOWN & $3.88 * * *$ & 0.80 & $0.44 * * *$ & 0.12 \\
\hline MOTORBIKE & -0.33 & 0.33 & -0.04 & 0.04 \\
\hline \multicolumn{5}{|l|}{ Social Capital } \\
\hline EXTENSION & -0.08 & 0.10 & -0.01 & 0.01 \\
\hline GROUP & $-2.86^{* *}$ & 1.03 & $-0.32 * * *$ & 0.11 \\
\hline \multicolumn{5}{|l|}{ Market Access } \\
\hline CONTRACT & $6.18^{* * *}$ & 1.37 & $0.70^{* * *}$ & 0.21 \\
\hline DISTANCE & 0.17 & 0.13 & $0.02 *$ & 0.01 \\
\hline \multicolumn{5}{|l|}{ Regional Dummy } \\
\hline Soil & -0.23 & 1.00 & -0.03 & 0.11 \\
\hline Constant & $-13.11 * * *$ & 4.79 & & \\
\hline Log likelihood & -50.93 & & & \\
\hline LR Chi ${ }^{2}$ & $213.93 * * *$ & & & \\
\hline Pseudo $\mathrm{R}^{2}$ & 0.68 & & & \\
\hline Percent corrected value & $92 \%$ & & & \\
\hline
\end{tabular}

Note. Data from author's survey in 2015. Number of Observations is $271 . * * * p<0.01,{ }^{* *} \mathrm{p}<0.05,{ }^{*} \mathrm{p}<0.10$.

Although the Indonesia government supported the agricultural sector by providing loans with low interest rates and long-term installment plans, we still found a significant role of land certificate ownership in increasing the probability of a farmer expanding his or her oil palm farm size (effect size about 0.44 , keeping other variables constant). Based on the field observation, we found that land property right become the important element of farmland expansion, particularly when farmers need a collateral for borrowing money from finance institution (in the study site, credit providers are devided into two which are bank and non-bank). To This finding is consistent with a report by USAID (2010), which encouraged the Indonesian government to implement land tenure rights to protect the livelihoods of local people dependent on natural resources for their main income.

As for the family labor variable, a one-hour increase in the total family working time increased the likelihood of expanding farmland by 0.02 . Having more family members actively involved in the plantation is important to increase productivity and reduce the cost of hiring labor when expanding plots size. Our observations during the survey suggested that farmers' groups disseminate farming guidance from refineries under contract schemes. Thus, we can conclude that farmers generally expanded their oil palm farms because of their personal preferences. These findings represent an interesting area for future research. As explained earlier, farmers in the study area obtained agricultural education through extension contact or social interactions within farmers' organizations. Contrary to our prediction, extension visits had a negative but statistically insignificant impact on the likelihood that a farmer would expand his or her oil palm farm. In addition, we also found that farmers were less likely to expand their oil palm farms if they were members of a farmers' association, with the marginal effect is -0.32 . These findings emphasize that extension services and farmers' organizations in the study area do not serve to encourage farmers to expand farmland. 
Table 5. Matching quality indicator

\begin{tabular}{|c|c|c|c|c|c|}
\hline \multirow{2}{*}{ Matching Method } & \multicolumn{2}{|c|}{ Pseudo $\mathrm{R}^{2}$} & \multicolumn{2}{|c|}{ LR chi $^{2}$ (p-value) } & \multirow{2}{*}{$\begin{array}{l}\text { Mean standardized } \\
\text { bias after matching }\end{array}$} \\
\hline & Before & After & Before & After & \\
\hline $\mathrm{NNM}^{\mathrm{a}}$ & 0.68 & 0.11 & $213.93 * * *$ & 63.83 & 15.3 \\
\hline $\mathrm{NNM}^{\mathrm{b}}$ & 0.68 & 0.16 & $213.93 * * *$ & 89.06 & 18.0 \\
\hline $\mathrm{KBM}^{\mathrm{c}}$ & 0.68 & 0.12 & $213.93 * * *$ & 67.47 & 18.2 \\
\hline $\mathrm{KBM}^{\mathrm{d}}$ & 0.68 & 0.12 & $213.93 * * *$ & 67.01 & 16.3 \\
\hline
\end{tabular}

Table 6. Average treatment effect of expanding oil palm farm size

\begin{tabular}{|c|c|c|c|c|c|c|c|}
\hline \multirow{2}{*}{ Outcome } & \multirow{2}{*}{ Matching Method } & \multicolumn{3}{|c|}{ ATT } & \multicolumn{3}{|c|}{ ATU } \\
\hline & & Exp. & Non-Exp. & Dif. & Exp. & Non-Exp. & Dif. \\
\hline \multirow{4}{*}{$\begin{array}{l}\text { Crop Income } \\
\text { (Million IDR) }\end{array}$} & $\mathrm{NNM}^{\mathrm{a}}$ & 108.82 & 45.32 & $63.49 * * *$ & 83.58 & 46.29 & $37.29 * * *$ \\
\hline & $\mathrm{NNM}^{\mathrm{b}}$ & 108.82 & 46.53 & $62.28 * * *$ & 105.27 & 37.29 & $67.98 * * *$ \\
\hline & $\mathrm{KBM}^{\mathrm{c}}$ & 108.82 & 48.01 & $60.80 * * *$ & 98.30 & 48.45 & $49.85^{* * *}$ \\
\hline & $\mathrm{KBM}^{\mathrm{d}}$ & 109.57 & 46.32 & $63.25 * * *$ & 96.30 & 49.30 & $46.99 * * *$ \\
\hline \multirow{4}{*}{ Wellbeing status (\%) } & $\mathrm{NNM}^{\mathrm{a}}$ & 0.70 & 0.56 & 0.14 & 0.57 & 0.21 & $0.36^{* * *}$ \\
\hline & $\mathrm{NNM}^{\mathrm{b}}$ & 0.81 & 0.56 & $0.25 * *$ & 0.60 & 0.57 & 0.03 \\
\hline & $\mathrm{KBM}^{\mathrm{c}}$ & 0.72 & 0.56 & $0.16^{*}$ & 0.71 & 0.39 & $0.32 * * *$ \\
\hline & $\mathrm{KBM}^{\mathrm{d}}$ & 0.69 & 0.56 & 0.13 & 0.71 & 0.38 & $0.33^{* * *}$ \\
\hline
\end{tabular}

Note for Table 5 and 6. Outcome data from author's survey in 2015. IDR = Indonesian Rupiah, 1 USD = 13,000 IDR. Wellbeing status was measured as dummy variable where 1 denotes PCE not less than 1 USD and 0 otherwise. $\mathrm{NNM}^{\mathrm{a}}=$ single $\mathrm{NNM}$ with replacement and common support, $\mathrm{NNM}^{\mathrm{b}}=$ five $\mathrm{NNM}$ with replacement and common support, $\mathrm{KBM}^{\mathrm{c}}=\mathrm{KBM}$ with bandwidth 0.06 and common support; $\mathrm{KBM}^{\mathrm{d}}=\mathrm{KBM}$ with bandwidth 0.03 and common support. Exp. is Expansion Group, Non-Exp. is Non-Expansion Group, and Dif. is Difference. $* * * \mathrm{p}<0.01, * * \mathrm{p}<0.05, * \mathrm{p}<0.10$.

Market access variables are shown to have positive and significant impacts on likelihood of oil palm farm size expansion. The marginal effect of the variable indicating contract farming implies that if farmers have agreements with refineries, they are more likely to expand their farmland by a factor of 0.70 , other variables held constant. Marketing agreement can ensure that oil palm farmers are able to sell their products right after harvesting. Thus, it is more likely that the price of oil palm fruit will approach the global market price. Market distance also contributes (effect size of 0.02) to raising the probability that a farmer will choose to expand his or her farmland. Since oil palm fruit degrade if stored for a long time, selling the fruit quickly after harvesting has advantages, even if it means that the farmer might face the price prevailing on a given day. On the other hand, some remote areas lack roads connecting oil palm plots to refineries; farmers thus face unexpected situations such as road blockages, traffic jams, and accidents when transporting oil palm fruit.

\subsection{Effects of Expanding Oil Palm Farm Size}

Before analyzing the causal effect of oil palm we test the indicators of matching quality before and after matching using the covariate balancing test (Table 5). Table 6 reports the estimates for the average farm size expansion effect estimated by the NNM and KBM methods (based on single and five nearest neighbor approaches) and the Epanechnikov kernel estimator with two different bandwidths (0.06 and 0.03). The standardized mean difference for overall covariates used in the propensity score is reduced to 15.3-18.2 after matching. The $p$-values for the likelihood ratio tests indicate that the joint significance of covariates could always be rejected after matching, whereas it was never rejected before matching. The pseudo $R^{2}$ dropped significantly, from $68 \%$ before to $11 \%-16 \%$ after matching. The low mean standardized bias and insignificant $p$-values in the likelihood ratio test after matching suggest that the proposed propensity score specification is fairly successful at balancing the distribution of covariates between the two groups.

The relationship between agricultural adoptions, particularly land expansion and poverty reduction is 
theoretically complex and further analysis regarding impact is necessary. All the causal effect analysis is based on the common support implementation; thus the distributions from the expansion and non-expansion groups are located in the same domain. The outcome variables are net oil palm income per unit of landholding size and the household poverty headcount ratio based on daily consumption. Results indicate that farm size has a positive and significant effect, increasing oil palm income from 60.80 to 63.49 million IDR per year. This suggests that expanding farmers made the right decision to expand their farm size. For the non-expansion group, it was found that their income would increase from 37.29 to 67.98 million IDR per year were they to expand their land. These results imply that expanding oil palm farmland was the right decision for both groups.

The results also show some poverty reduction, as proven by the higher percentage of farm households with per capita expenditures significantly above the poverty line, ranging by $16 \%$ to $25 \%$, implying again that the expansion farmers made the right decision in terms of expanding oil palm farm land. Considering the ATU results, non-expansion farmers would see a $32 \%$ to $36 \%$ decreases in poverty were they to shift to the expansion group. Overall, these findings align with previous studies in which oil palm expansion was found to have a positive impact on improving farmers' household welfare and providing a source of income, particularly in Indonesia and other developing countries. In addition, Obidzinski et al. (2012), who studied the social impact of oil palm plantations in three other plantation regions in Indonesia (West Papua, West Kalimantan, and Papua), reported that most smallholder farmers improved their livelihood conditions due to higher incomes, better housing, broader social networks, and improved access to infrastructure.

\section{Conclusion}

This study estimated the causal effect of expanding oil palm farm size on income and poverty reduction in rural Indonesia. Propensity score matching was used to examine the outcomes of the expansion process, with a model accounting for selection bias based on observable differences between the treated and untreated groups. The empirical analysis indicated that expanding oil palm farm size raised farmers' oil palm incomes and thereby helped reduce poverty. Specifically, farmers in both the expansion and non-expansion groups were shown to be able obtain higher incomes than if the other farmers that had not expanded farm sizes. However, both groups seemed to have made the right decisions in terms of expanding oil palm farm size. On average, expanding oil palm farms has a positive effect on poverty alleviation; with the results suggesting that farm size expansion increases the percentage of households living above the poverty line.

The overall conclusion of the analysis is that oil palm farm expansion can be an important strategy for smallholder farmers to increase their incomes and improve their welfare. Oil palm expansion, however, is driven by human capital availability, particularly the availability of family members who can be actively involved in farming practices, financial assets such as credit support from financial institutions land ownership certification, and market variables (including participation in a contract farming scheme and market access). On the other hand, oil palm expansion seems to be constrained by a lack of technical guidance. As such, extension service programs and the effectiveness of farmers' groups should be considered as future topics for government policy to address.

The factors driving oil palm expansion should be taken into account when trying to improve Indonesia's oil palm expansion program. We captured three important supporting factors that can help sustain future expansion, including improving human resources availability, particularly for the farm's successor because of most of the household heads in this study were relatively elderly, enhancing links between smallholders and refineries for selling oil palm products, and building sufficient infrastructure facilities to allow oil palm farmers to transport oil palm products to refineries and to buy agricultural material. To understand the full potential of oil palm expansion for improving farm households' livelihoods, however, additional research must quantify the food security status in response to the income earning form oil palm, and determine how the effects of expansion vary with farm size. Thus, it is expected to clarify the actual impact of oil palm expansion to the smallholders' livelihood in Indonesia.

\section{Acknowledgements}

The authors would like to acknowladge the supports from the Indonesia Endowment Fund for Education (LPDP). Also, we thank the editor and two anonymous revierwers for the constructive comments on this article.

\section{References}

Ali, A., \& Abdulai, A. (2010). The adoption of genetically modified cotton and poverty reduction in Pakistan. Journal of Agriculture Economics, 61(1), 175-192. http://dx.doi.org/10.1111/j.1477-9552.2009.00227

Alwarritzi, W., Nanseki, T., \& Chomei, Y. (2015a). Analysis of the factors influencing technical efficiency 
among oil palm smallholder farmers in Indonesia. Procedia Environmental Sciences, 28, 630-638. http://dx.doi.org/10.1016/j.proenv.2015.07.074

Alwarritzi, W., Nanseki, T., \& Chomei, Y. (2015b). Factors determining household level farmers' decission to expand oil palm farmland in Indonesia. Journal of the Faculty of Agriculture, Kyushu University, 60(2), 563-568. http://catalog.lib.kyushu-u.ac.jp/handle/2324/1543428/p563.pdf

Barbier, E. B. (2004). Explaining agricultural land expansion and deforestation in developing countries. American Journal of Agricultural Economics, $1347-1353$. http://dx.doi.org/10.1111/j.0002-9092.2004.00688

Cahyadi, E. R., \& Waibel, H. (2013). Is contract farming in the Indonesian oil palm industry pro-Poor? Journal of Southeast Asian Economics, 30(1), 62-67. http://dx.doi.org/10.1355/ae30-1d

Cramb, R., \& Curry, G. N. (2012). Oil palm and rural livelihoods in the Asia-Pacific region: An overview. Asia Pacific Viewpoint, 53(1), 223-239. http://dx.doi.org/10.1111/j.1467-8373.2012.01495.x

Deaton, A. (2003). Household surveys, consumption, and the measurement of poverty. Economic System Research, 15(2), 135-159. http://dx.doi.org/10.1080/0953531032000091144

Dimara, E., \& Skuras, D. (1998). The adoption of new tobacco varieties in Greece: Impact of empirical findings $\begin{array}{lllll}\text { on policy design. } & \text { Agricultural }\end{array}$ http://dx.doi.org/10.1016/S0169-5150(98)00041-3

Ditjenbun (General Director of Crop Estate). (2015). Statistik Komoditas Perkebunan Kelapa Sawit. Retrieved April 23, 2015, from http://ditjenbun.pertanian.go.id

Elias, A., Nohmi, M., Yasunobu, K., \& Ishida, A. (2013). Effect of agricultural extension program on smallholders' farm productiveity: Evidence from three peasent associateons in highland of Ethiopia. Journal of Agricultural Science, 5(8), 163-181. http://dx.doi.org/10.5539/jas.v5n8p163

Finan, F., Sadoulet, E., \& Janvry, A. D. (2005). Measuring the poverty reduction potential of land in rural Mexico. Journal of Development Economics, 77, 27-51. http://dx.doi.org/10.1016/j.jdeveco.2004.02.004

Fischer, E., \& Qaim, M. (2012). Linking smallholders to market: Determinants and impacts of farmer collective action in Kenya. Food Security, 40(6), 1255-1268. http://dx.doi.org/10.1016/j.worlddev.2011.11.018

Food and Agricultural Organization of the United Nation (FAO). (2014). FAOSTAT Production Statistics. FAO, Org. Retrieved June 25, 2015, from http://faostat3.fao.org

Gatto, M., Wollni, M., \& Qaim, M. (2015). Oil palm boom and land-use dynamics in Indonesia: The role of policies and socioeconomic factors. Land Use Policy, 46, 292-303. http://dx.doi.org/10.1016/j.landusepol.2015.03.001

Greene, W. (2013). Econometric Analysis (7th ed.). New York: New York University Press.

Hassink, J., Hulsink, W., \& Grin, J. (2012). Care farms in the Netherlands: An underexplored example of multifunctional agriculture - Toward an empirically grounded, organization-theory-based typology. Rural Sociology, 77(4), 1-32. http://dx.doi.org/10.1111/j.1549-0831.2012.00089.x

Herath, P., \& Takeya, H. (2003). Factors determining intercropping by rubber smallholders in Sri Lanka: A logit analysis. Agricultural Economics, 29(2), 159-168. http://dx.doi.org/101111/j.1574-0862

Jones, A. D., Shrinivas, A., \& Bezner, K. R. (2014). Farm production diversity is associated with greater household dietary diversity in Malawi: Findings from nationally representative data. Food Policy, 46, 1-12. http://dx.doi.org/10.1016/j.foodpol.2014.02.001

Krishna, V. V., Euler, M., Siregar, H., Fathoni, Z., \& Qaim, M. (2015). Farmer heterogeneity and differential livelihood impacts of oil palm expansion among smallholders in Sumatra, Indonesia. Goettingen, Germany: EFForTS Discussion Paper (13). Retrieved from http://resolver.sub.uni-goettingen.de/purl/?webdoc-3956

McCarthy, J. (2010). Processes of inclusion and adverse incorporation: Oil palm and agrarian change in Sumatra, Indonesia. The Journal of Peasant Studies, 437 37(4), http://dx.doi.org/10.1080/03066150.2010.512460

Mital, S., \& Kumar, P. (2000). Literacy, technology, adoption, factor demand and productivity: An econometric analysis. Indian Journal of Agricultural Economics, 55(3), 490-499. http://dx.doi.org/10.1111/j.1574-0862.2003.tb00154

Obidzinski, K., Andriani, R., Komarudin, H., \& Andrianto, A. (2012). Environmental and social impacts of oil 
palm plantation and their implications for biofuel production in Indonesia. Ecology and Society, 17(1), 25. http://dx.doi.org/10.5751/ES-04775-170125

Pellegrini, L., \& Tasciotti, L. (2014). Crop diversification, dietary diversity and agricultural income: Empirical evidence from eight developing countries. Canadian Journal of Development Studies, 35(2), 211-227. http://dx.doi.org/10.1080/02255189.2014.898580

Rahman, S. (2008). Determinants of crop choices by Bangladeshi farmers: A bivariate probit analysis. Asian Journal of Agriculture and Development, 5(1), 29-41. http://dx.doi.org/10.4172/2332-2594.1000120

Rist, L., Feintrenie, L., \& Levang, P. (2010). The livelihood impact of oil palm: Smallholders in Indonesia. Biodiversity Conservation, 19, 1009-1024. http://dx.doi.org/10.1007/s10531-010-9815

Sinsesi, B. (2004). An evaluation of the Swedish system of active labour market programmes in the 1990s. Review of Economics and Statistics, 41, 1-42. http://dx.doi.org/10.1920/wp.ifs.2002.0201

UNDP (United Nations Development Program). (2015). Indonesia Palm Oil Platform. Retrieved from http://www.undp.org/content/undp/en/home/ourwork/environmentandenergy/projects_and_initiatives/green -commodities-programme/projects/palm-oil.html

USAID (United States Agency for International Development). (2010). Indonesian Land Tenure Profile. Retrieved from http://www.usaidlandtenure.net/indonesia

Verhofstadt, M., \& Maertens, M. (2014). Can agricultural cooperative reduce poverty? Heterogenous impact of cooperative membership on farmers' welfare in Rwanda. Applied Economic Perspective and Policy Advance, O(0), 1-21. http://dx.doi.org/10.1093/aepp/ppu021

Yu, X., Gao, Z., \& Zeng, Y. (2014). Willingness to pay for the "Green Food" in China. Food Policy, 45, 80-87. http://dx.doi.org/10.1016/j.foodpol.2014.01.003

\section{Copyrights}

Copyright for this article is retained by the author(s), with first publication rights granted to the journal.

This is an open-access article distributed under the terms and conditions of the Creative Commons Attribution license (http://creativecommons.org/licenses/by/3.0/). 